following factors: (a) a true change in the permeability of the muscle cell membrane to galactose due to physical and/or chemical changes in the membrane environment during fasting $(p \mathrm{H}$, ionic composition, hormonal influences, etc.); (b) a change in the equilibrium state of the sugar-carrier system $^{9}$ of the membrane as a result of ehanged intracellular free glucose concentration; (c) (increased ?) utilization of galactose; and $(d)$ an artefact due to the inadequacy of reduction methods ${ }^{10}$ for sugar determination.

No conclusive evidence of any one of these factors operating in the fasted state has been obtained; a detailed report of the experiments and their results together with an analysis will be published in another connexion.

Physiological Department,

Institute of Occupational Health,

Helsinki.

Jan. 26.

1 Reinius, L., Ann. Acad. Scient. Fennicae, A., 2, 49 (1953).

- Umbreit, W. W., Burris, R. H., and Stauffer, J. F., "Manometric Techniques and Tíssue Metabolism" (Burgess Pub. Co., Minneapolis, 1949).

somogyi, M., J. Biol. Chem., 195, 19 (1952).

- Nelson, N. J., J. Biol. Chem., 153, 375 (1944).

- Holmberg, N. G., Kaplan, B., Karvonen. M. J., Lind, J., and Malm, M., Acta Physiol. Scand., 36, 291 (1956).

- Haft, D. I., Mirsky, A., and Perisutti, G., Proc. Soc. Exp. Biol. and Med., 82,60 (1953).

'Soskin, S., and Levine, R., "Carbohydrate Metabolism" (Univ. Chicago 'Press, Chicago, 1952).

- Nakada, H, I., and Wick, W. N., Amer. J. Physiol., 185, 23 (1956).

- LeFevre, P. G.. "Active Transport through Animal Cell Membraneg" (Springer-Verlag, Wien, 1955).

10 Randle, P. J., Nature, 178. 983 (1956).

\section{Inhibition by Thyroxine of Enzymes requiring Pyridoxal-5-Phosphate}

SINCE vitamin $B_{B}$ is beneficial to rats treated with thyroxine ${ }^{1}$, the activity of some enzymes known to require pyridoxal-5-phosphate has been determined in the liver of rats treated with thyroxine.

The rats received $10 \mu \mathrm{gm}$. of DL-thyroxine (B.D.H.), during fifteen days. The activity of cysteine disulphhydrase, serine and threonine dehydrases, alanineglutamic and aspartic-glutamic transaminases was measured in the liver homogenates (technique of Tonhazy et al. ${ }^{2}$ ).

It was found that cysteine disulphhydrase activity disappeared from the livers of the treated rats, and serine and threonine dehydrases and alanine-glutamic transaminase activity were reduced by 40 per cent as compared with normal values. Aspartic-glutamic transaminase showed little change. By in vitro addition of 0.05 micromole of pyridoxal-5-phosphate to the enzyme preparations, these inhibitions were reversed to the normal level. Likewise, these inhibitions did not appear if, simultaneously with thyroxine, pyridoxine-hydrochloride was administered to the animals, $5 \mathrm{mgm}$./rat/day, during 15 days.

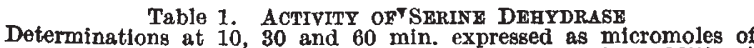
pyruvate formed per gram of dry weight liver (in vitro additions)

\begin{tabular}{|c|c|c|c|c|}
\hline & $\begin{array}{c}\text { Enzyme } \\
\text { alone }\end{array}$ & $\begin{array}{c}\text { Enzyme } \\
0.05 \mathrm{~m} M \\
\text { pyr.-5- } \\
\text { phos. }\end{array}$ & $\begin{array}{c}\text { Enzyme } \\
0.025 \mathrm{~m} M \\
\text { thyroxine }\end{array}$ & $\begin{array}{c}\text { Enzyme } \\
0.025 \mathrm{~m} M \text { thyroxine } \\
0.05 \mathrm{~m} M \text { pyr.-5-phos. }\end{array}$ \\
\hline $10 \mathrm{~min}$. & 33 & 60 & 16 & 53 \\
$30 \mathrm{~min}$. & 66 & 165 & 33 & 132 \\
$60 \mathrm{~min}$. & 90 & 263 & $39 \cdot 6$ & 224 \\
\hline
\end{tabular}

In vitro addition of 0.025 micromole of vL-thyroxine at $p \mathrm{H} 7 \cdot 4$ to normal liver homogenates produced similar inhibitions, though of lesser degree, to those found in the animal treated with thyroxine. This in vitro inhibition was also completely reversed by addition of 0.05 micromole of pyridoxal-5-phosphate.

This interrelationship between a hormone and a coenzyme is being studied further. However, in the light of Snell's theory of the formation of a Schiff base between an amino-acid and pyridoxal-5-phosphate, it seems that these inhibitions mean more than just a higher nutritional requirement of the vitamin in the hyperthyroid state. It could be part of the mechanism of action of the hormone.

Institute of Physiology, Santiago, Chile.

$$
\text { Jan. } 29 .
$$

${ }^{2}$ Drill, v. A., and Overman, R., Amer. J. Physiol., 135, 474 (1942). 2 Tonhazy, F., Arch. Biochem., 88, 36 (1950).

\section{Actively Acquired Tolerance to Tuberculo- Protein}

ANIMALs confronted in fœetal life, or shortly after birth, with antigenic substances may fail to develop an antibody response to such antigens in adult life. This inhibition of antibody response, termed 'actively acquired tolerance', is antigenically highly specific, and has been demonstrated with several unrelated antigens ${ }^{1}$.

The possibility of rendering animals incapable of specific antibody responses by fotal inoculation suggests a new approach to the study of acquired immunity to infectious disease. It is often difficult to assess the significance of a particular antibody response to immunity because several responses may be elicited simultaneously by the different antigens of the infecting micro-organism. Such an assessment might be possible, however, by comparing animals capable of a response to a specific antigen with animals rendered immunologically tolerant to it. In connexion with a study of the role of delayed-type hypersensitivity to tuberculo-protein (tuberculin sensitivity) in immunity to tuberculosis, we attempted to eliminate tuberculin sensitivity in the guinea pig by injecting the foetuses with tuberculo-protein and whole tubercle bacilli.

Pregnant guinea pigs were subjected to laparotomy and the foetuses injected through the uterine wall with one of the following substances : $1 \mathrm{mgm}$. (100 tuberculin units) of Old Tuberculin; $1 \mathrm{mgm}$., wet weight, tubercle bacilli of the attenuated B.C.G. strain, killed by heating at $70^{\circ} \mathrm{C}$. for $10 \mathrm{~min}$.; or $0.5 \mathrm{mgm}$., wet weight, living B.C.G. The volume of the inocula was $0.1 \mathrm{ml}$. The time of injection varied from one to forty-six days before birth.

Of 250 .guinea pigs operated on, less than 5 per cent died as a result of the operation, and more than half delivered living young. When the young had reached a weight of $250 \mathrm{gm}$., they were tested for tuberculin sensitivity by the intradermal injection of $0.2 \mathrm{ml}$. of a $1: 10$ dilution of Old Tuberculin $(2,000$ tuberculin units). Skin reactions were observed over a period of $72 \mathrm{hr}$. The reactions were considered positive if the area of induration exceeded $6 \mathrm{~mm}$. in diameter. After the initial tuberculin test, the animals were vaccinated intraperitoneally with either $200 \gamma$ or $800 \gamma$, dry weight, of phenol-killed tubercle 